\title{
The Impact of Top Management Team Nationality Diversity and International Experience on Foreign Entry Mode
}

\author{
Nielsen, Bo Bernhard; Nielsen, Sabina
}

Document Version

Final published version

Publication date:

2009

License

CC BY-NC-ND

Citation for published version (APA):

Nielsen, B. B., \& Nielsen, S. (2009). The Impact of Top Management Team Nationality Diversity and International Experience on Foreign Entry Mode. Center for Strategic Management and Globalization. SMG Working Paper No. 8/2009

Link to publication in CBS Research Portal

\footnotetext{
General rights

Copyright and moral rights for the publications made accessible in the public portal are retained by the authors and/or other copyright owners and it is a condition of accessing publications that users recognise and abide by the legal requirements associated with these rights.

Take down policy

If you believe that this document breaches copyright please contact us (research.lib@cbs.dk) providing details, and we will remove access to the work immediately and investigate your claim.
}

Download date: 26. Apr. 2023 
The Impact of Top Management Team Nationality Diversity and International Experience on Foreign Entry Mode

\author{
Bo B. Nielsen \\ Sabina Nielsen
}

SMG WP 8/2009

November 4, 2009 
SMG Working Paper No. 8/2009

November 4, 2009

ISBN: 978-87-91815-49-2

Center for Strategic Management and Globalization Copenhagen Business School

Porcelænshaven 24

2000 Frederiksberg

Denmark

www.cbs.dk/smg 
THE IMPACT OF TOP MANAGEMENT TEAM NATIONALITY DIVERSITY AND INTERNATIONAL EXPERIENCE ON FOREIGN ENTRY MODE

\author{
Bo Bernhard Nielsen* \\ Copenhagen Business School \& University of Technology Sydney \\ Center for Strategic Management and Globalization \\ Porcelaenshaven 24B \\ 2000 Frederiksberg \\ Denmark \\ Phone: +4538152529 \\ Fax: +4538153035 \\ Email: bn.smg@cbs.dk
}
$\&$
Sabina Nielsen
Copenhagen Business School \& University of Technology Sydney
Department of International Economics and Management
Porcelaenshaven 24B
2000 Frederiksberg
Denmark
Phone: +4538152524
Fax: +4538152400
Email: sta.int@cbs.dk

* Corresponding Author.

Acknowledgements: Bo Nielsen acknowledges the support of the Marie Curie International Re-Integration Grant MIRG-CT-2007-046447; Sabina Nielsen acknowledges the support of the Marie Curie European Re-Integration Grant PERG042008-239310. 


\begin{abstract}
Nationality diversity and international experience constitute two related yet distinct sources of competence among upper echelons. While both TMT international experience and nationality diversity increases the likelihood of firms expanding outside their home region, our results show that TMTs with international experience are more likely to expand abroad via greenfield investments, whereas nationally diverse TMTs are more likely to engage in international acquisitions and joint ventures. This highlights the need to treat TMT nationality diversity and international experience as two different characteristics influencing foreign entry mode decision.
\end{abstract}

Keywords: Top management team, nationality diversity, international strategic decisionmaking, foreign entry mode. 


\section{Introduction}

The international business literature traditionally assumes that internationalization decisions are purely rational and scholars tend to ignore strategic decision-making research in explaining how foreign investment decisions are made (Brouthers \& Hennart, 2007). However, foreign expansion does not occur in a vacuum, but is determined by a certain set of strategic choices made my executive decision-makers (Herrmann \& Datta, 2005; Park \& Lee, 2008). Based on the behavioral theory of the firm (March \& Simon, 1958; Cyert \& March, 1963), strategic decision-making research focuses on how decisions are conditioned by bounded rationality.

For instance, upper echelons theory suggests that executives' backgrounds and experiences greatly influence their interpretations of strategic decision-making situations, and, in turn, affect their choices (Hambrick \& Mason, 1984). A large body of research has linked managers education, functional background, age, tenure etc. to a number of strategic and performance outcomes. The link between TMT characteristics and firm strategic choice is part of a growing stream of research preoccupied with executive effects on the sequence and consequences of firm's competitive actions (Cannella, Finkelstein \& Hambrick, 2008; Carpenter et al., 2004). For instance, Ferrier (2001) found TMT heterogeneity to be positively associated with the propensity to initiate competitive attacks of greater complexity. Others have linked executive characteristics to alliance formation (Eisenhardt \& Schoonhoven, 1996), diversification and acquisitions (Jensen \& Zajac, 2004).

Lately, this line of enquiry has been extended to the global arena. The increase in market globalization over the past decades and the ensuring pressures on top management 
to internationalize their firms puts a premium on decision-makers with international backgrounds and orientations. Internationally competent top management teams (TMTs) are believed to be better at coping with diverse cultural, institutional, and competitive environments and make strategic decisions that result in superior performance (Bartlett \& Ghoshal, 1989; Gupta \& Govindarajan, 2002). Research has linked TMT characteristics, particularly international experience, to firm international involvement (Athanassiou \& Nigh, 2002, Reuber \& Fisher 1997, Sambharya 1996, Tihanyi et al. 2000; Wally \& Beccerra, 2001). Yet, the potential value of heterogeneity in executive's nationalities and the cultural composition of the TMT has thus far been neglected, constituting a critical omission in our understanding of international strategic decision-making (Cannella, Finkelstein \& Hambrick, 2008).

While both international experience and nationality diversity are beneficial for international decision-making, they lead to different preferences and choices. We argue that the nationality of top executives influences their cognitions and values and determines their preferences for certain types of strategic actions. In addition to bringing broader international business knowledge and network contacts, nationality determines the content and structure of cognitive schemas and thus influences the way top managers collect, process, organize, and use information (Shaw, 1990). Together with the deeply rooted cultural values of the executive's country of origin, these cognitive bases create a filter through which information is selected and interpreted, which, in turn, provides the basis for strategic choice (Hambrick \& Mason, 1984). In a TMT setting, the diversity in cognitive bases and values resulting from executive nationalities has a strong influence on strategic decision-making. 
The contribution of this paper is to compare and contrast international experience and nationality diversity in order to illuminate their distinct roles in international strategic decision-making. We argue that while international experience and nationality diversity are both positively associated with international expansion outside the home region, their influence on foreign entry mode is likely to differ. Specifically, we expect TMT nationality diversity to increase the probability of engaging in culturally complex international strategic decision, such as international acquisitions and joint ventures, whereas international experienced TMTs are more likely to prefer greenfield investments as mode of entry into foreign markets. We test out propositions on a sample of 95 Swiss firms over a period of 7 years (2001-2007).

\section{Theory}

\subsection{Behavioral theory of internationalization}

One of the fundamental questions in international business is how firms expand beyond their national borders. Much of this literature is grounded in economic theory with a strong focus on rational choice in relation to cost-minimization and risk-adjusted return on investment (e.g., Anderson \& Gatignon, 1986; Hennart, 1988; Willamson, 1985). An alternative explanation, rooted in the behavioral theory of the firm (Cyert \& March, 1963), recognizes the influence of bounded rationality on the part of decision-makers and emphasizes experiential learning as the driving force behind the internationalization process of the firm (Johanson \& Vahlne, 1977).

Johanson and Vahlne (1977) predicted that firms will incrementally build foreign operations, starting with low resource commitment in culturally proximate countries, and 
only gradually expand these commitments and geographic scope to "psychically distant" countries based on learning. It is suggested that firms will successively enter countries with increasing "psychic distance", where psychic distance is defined as factors that may act as barriers to international expansion. Such factors may include institutional, cultural, and political factors that prevent or disturb the flow of information or knowledge between the firm and the target country (Benito \& Gipsrud, 1992; Johanson \& Wiedersheim-Paul, 1975). For instance, cultural distance has long been associated with high risks and thus firms are less likely to invest in culturally distant markets (Shenkar, 2001).

According to the behavioral theory of internationalization, lacking routines for overcoming psychic distance, managers search in the neighborhood of their past experiences and, as a result, firms tend to stay in the vicinity of their past practices and the routines which govern them (Cyert \& March, 1963; Johanson \& Vahlne, 1977). These arguments are consistent with what Rugman and Verbeke (2004: 16) refer to as a natural preference for regionally based activities. Investigating the 500 largest MNCs in the world, they provided evidence that firms are most likely to undertake economic activity in their home region, where the psychic distance is considered relatively low. Expanding outside the home region is associated with high levels of complexity and uncertainty related to international strategic decisions (Sanders \& Carpenter, 1998).

A second prediction of the IP model relates to the increasing level of commitment to foreign markets through successive stages of the establishment chain (Johanson \& Vahlne, 1977). This is consistent with the literature on entry mode choice, which suggests that different modes of foreign entry represent different levels of resource commitment, risk, and control (Anderson \& Gatignon, 1986). According to this view, a joint venture 
(JV) is the pooling of assets in a common and separate organization by two or more firms, resulting in lower commitment and shared ownership, risk, and control. Wholly owned subsidiaries (WOS), on the other hand, are chosen when firms seek maximum control and are willing to make maximum commitment and take on maximum risk (Kogut \& Singh, 1988). Wholly owned subsidiaries, in turn, can be separated into at least two categories; greenfield investments vs. acquisitions. While the entry mode choice (JV vs. WOS) is concerned with the level of ownership, the choice of establishment mode (greenfield vs. acquisition) is related to the nature of the investment; whether to invest in new facilities or acquire existing ones.

Some researchers advocate a theoretical and empirical distinction between these two decisions based on the notion that they represent independent choices (e.g., Brouthers \& Hennart, 2007; Hennart \& Park, 1993). Others, however, argue that JVs are not merely a matter of ownership but also of underlying strategic motives, and managers are thus likely to consider them simultaneously with other entry mode choices (Kogut \& Singh, 1988). Both views are grounded in rational choice models and lack attention to the role of managerial characteristics. In this study, our main proposition is that managerial characteristics are likely to determine preferences for certain types of foreign entry modes. Thus, rather than examining the choice of one mode of entry over another as the result of rational measurable assessments of risk, control, and commitment, we focus on the propensity to engage simultaneously in multiple foreign entry strategies as a result of the influence of TMT backgrounds and experiences on international strategic decisionmaking. Consistent with the behavioral theories of internationalization we distinguish between entry modes based on their level of cultural complexity and argue that 
international acquisitions and joint ventures are associated with higher cultural complexity compared to greenfield investments. TMTs with different experiences and nationalities are likely to favor different entry mode strategies.

\subsection{Behavioral strategic decision-making and nationality diversity}

The most fundamental challenge faced by top managers is to process many, complex, and often ambiguous stimuli when making strategic decisions under high uncertainty (Starbuck \& Milliken, 1988). In such situations, the stimuli do not clearly point to ideal choices; instead top executives are confronted with far more information, both from within and outside the organization, than they can possibly fully comprehend. As noted by March and Simon (1958: 169), "because of the limits of human intellective capacities in comparison with the complexities of the problems that individuals and organizations face, rational behavior calls for simplified models that capture main features of a problem without capturing all its complexities". Research has demonstrated that humans attempt to reduce cognitive effort through the use of heuristics (or "rules of thumb") and cognitive structures (schemas) to integrate pieces of information into a single judgment in making decisions (March \& Simon, 1958; Schwenk, 1984). Specifically, top managers employ their existing cognitive schemas and heuristics to organize and process information efficiently and simplify the decision process (Shaw, 1990). In this way, decision-makers can make fairly accurate interpretations and evaluations without having to examine all available information.

While facilitating information-processing, the use of prior experiences, cognitive schemas and heuristics may, however, create systematic biases and lead to potential error 
in decision-making (Tversky \& Kahnemann, 1974). For instance, cognitive heuristics will reduce the number of variables included in decision makers' cognitive maps and, as a result, may lead to a smaller number of strategic alternatives being considered (Schwenk, 1988). The use of cognitive schemas may also encourage stereotype thinking, fill data gaps with typical yet potentially inaccurate information, prompt one to ignore discrepant and possibly important information, discourage disconfirmation of the existing knowledge structure, and inhibit creative problem solving (Walsh, 1995). Particularly in complex situations, decision makers rely on the familiar, often drawing on solutions that have worked well in the past (Cyert \& March, 1963). In this way, biases affect strategic decisions when existing experiences are used in diagnosing and framing new strategic problems. The more complex, unstructured, and strategic a decision is, the more likely it is that biases may influence the decision process (Duhaime \& Schwenk, 1985).

The cognitive schemas and heuristics are largely determined by executives' backgrounds and experiences (Schwenk, 1988). By the same token, upper echelons theory (Hambrick \& Mason, 1984) suggests that human limitations influence the perception, evaluation and decision about organizational problems and hence influence firm choices and behavior. The starting point of understanding the upper echelons perspective is March and Simon's (1958) notion that managers bring their own set of "givens", such as values and cognitive bases, to a decision-making situation. Thus, strategic choice is made not on the basis of an actual "real" situation, but rather on managers' perception, a so-called "construed reality" (Sutton, 1987). This argument is congruent with the behavioral view of Cyert and March that "the variables that affect choice are those that influence the definition of a problem within the organization" (1963: 
163). Similarly, Dutton, Fahey and Narayanan (1983: 310) argue that managers' "cognitive maps" play the role of a lens through which situations are viewed. Consistent with this, Prahalad and Bettis (1986) find that managers' cognitive schemas determine the approaches they are likely to use in resource allocation and control over operations.

According to upper echelons theory, observable demographic characteristics of top executives can be used to infer psychological cognitive bases and values and as such may serve as potent predictors of strategies (Hambrick \& Mason, 1984). One important yet largely neglected determinant of executives' strategic orientation and preferences is nationality. Cross-cultural psychology literature suggests that national origin ${ }^{1}$ influences underlying orientations and values as well as cognitions (Hofstede, 1980; Schwarz, 1992). These nationality-derived qualities, in turn, affect a person's behavior as well as how the person is perceived in a multinational team (Hambrick, Davison, Snell \& Snow, 1998). Much of the cultural patterns of thinking, feeling, and acting are acquired in early childhood because at that time a person is most susceptible to learning and assimilation. These patterns are deeply rooted and once they have established themselves within a person's mind, they are unlikely to change substantially through subsequent experiences (Hofstede \& Hofstede, 2005).

A limited number of studies explore the relationship between national culture and executive strategic orientation (e.g., Hitt, Tyler, Dacin \& Park, 1997). For instance, Geletkanycz (1997) demonstrated that cultural values significantly affect executives' openness toward change in the organizational status quo, even after controlling for earlier observed determinants such as experiential background. Similarly, Hambrick et al. (1998)

\footnotetext{
${ }^{1}$ We use nationality and culture interchangeably. While we acknowledge that different ethnic groups or subcultures may exist within a nation, these groups are likely to produce similar profiles on psychologically relevant attributes vis-à-vis those from other nations (Hofstede, 1980).
} 
argue that while accumulated international experience and exposure can, to some degree, surmount nationality-based differences, nationality imprinting is not easily erased. By the same token, Laurent (1983) found that the nationality of seasoned executives accounted for far more variations in the data than any of the respondents other characteristics, such as age, education, job, professional experience, hierarchical level, and company type. Hence, values traceable in part to the executive nationalities may affect executives' preferences for certain strategic actions. To this end, Gupta and Govindarajan (2002) argue that national culture affects strategic choices regarding how to enter and operate in international markets.

\section{Hypotheses}

\subsection{The role of nationality diversity in foreign expansion}

The outcome of foreign expansion decisions is highly uncertain and risky. In addition, the information necessary to be processed is difficult to access and interpret due to the "psychic distance" between the home and host country. As a result, foreign expansion decisions are likely to be influenced by the prior knowledge and experiences of decisionmakers. Prior research suggests that international assignment experience at the TMT level helps reduce the uncertainty associated with international expansion (Sambharya, 1996). For instance, international experience increases awareness of international opportunities (Tihanyi et al., 2000) and helps develop superior ability to manage operations in different countries. Specifically, the accumulated knowledge about foreign markets is important in overcoming the "psychic distance" of doing business abroad (Johanson \& Vahlne, 1977). In this way, international experience may serve a surrogate for cultural knowledge which 
is necessary for successfully formulating and implementing an international strategy (Sambharya, 1996). In addition, international experience helps establish informal networks that support decision-making in international contexts (Athnassiou \& Nigh, 2002; Roth, 1995). The knowledge, skills and network contacts, accumulated through international assignment experiences, enable TMTs to accurately scan the environments, select relevant information, and interpret decision-making situations. As such, learning associated with international experience is likely to lead to fewer mistakes, and, consequently, increased likelihood of success in foreign expansion (Herrmann \& Datta, 2002). A number of studies have demonstrated the positive association between firm internationalization and international experience of the CEO (Daily, Certo \& Dalton, 2000; Roth, 1995) as well as the entire TMT (Athanassiou \& Nigh, 2002; Carpenter, Sanders \& Gregersen, 2001; Sambharya, 1996; Tihanyi et al., 2000).

Foreign nationality among top executives may bring to international decisionmaking benefits similar to those of international experience. Diversity in TMT nationalities is likely to provide decision-makers with broader information resources, network contacts, skill sets, and cultural capital. As a result, nationally diverse TMTs are better able to accurately access, scan and interpret the available information in the international context. The knowledge and experiences, accumulated while living and working outside the country in which their company is based, influence the cognitive schemas of foreign born executives, which in turn determine their interpretation of a decision-making situation. The higher the diversity of executive nationalities, the higher the variety of cognitive schemas applied to finding solutions to a strategic problem. The varied views and perspectives enable nationally diverse TMTs to better comprehend and 
make sense of complex stimuli. Luo (2005) argues that cultural diversity in TMTs may be a source of reducing the information-processing costs of globalization because nationally diverse TMTs have greater processing capacity and can attend to more environmental cues and foreign liability problems (Zaheer, 1995), thus reducing the negative effects of psychic distance. Hence, nationally diverse TMTs are better equipped than homogenous teams with the knowledge and experience necessary to expand outside the home regions to countries with greater cultural, institutional, and political distance. By the same token, Punnett and Clemens (1999) found that nationally diverse teams ranked foreign expansion options significantly more attractive than did homogenous teams. Thus, we hypothesize that:

H1: The higher the TMT nationality diversity, the more likely the firm will expand outside the home region.

\subsection{International experience and foreign market entry}

Executives, who have accumulated knowledge of foreign cultures and business practices through international assignment experience, are better able to cope with uncertainty associated with international operations and thus they typically perceive foreign investments as less risky than executives without such experience (Carpenter et al., 2001). Internationally experienced top managers are likely to be confident in their ability to accurately estimate risks and returns associated with foreign investments and, as a result, be more aggressive in committing resources and assuming control over foreign operations (Erramilli, 1991). Moreover, to the extent that executives have worked abroad 
as expatriates they may be confident in their ability to transfer managerial skills and overcome the psychic distance of doing business abroad. As argued by Tung and Miller (1990), international assignment experience contributes to the development of a "global mindset" that leads to greater confidence in the ability to effectively handling global operations. Such confidence, however, can lead to certain biases, such as availability bias, selective perception and illusion of control (Schwenk, 1988).

Selective perception may lead to biases in the choice of variables relevant to strategic decision-making. For instance, a TMT consisting of members with extensive prior international assignment experience may be conditioned by their experiences to prefer modes of entry which rely on transferring managerial capabilities from headquarters to newly opened subsidiaries rather than sourcing knowledge from local management through joint ventures or acquisitions. By the same token, illusion of control leads to overestimation of control over outcomes. This may, in turn, bias TMTs to favor greenfield investments under the assumption that, although risky and costly, such investments are necessary in order to ensure success in culturally different markets. The success of an international assignment experience may also lead to availability bias, where the availability of easily-recalled events in executives' memories distorts their judgment of the probability of certain events occurring.

Multiple biases interact and reinforce each other in influencing strategic decisions (Schwenk, 1988). For instance, the perception selection bias might increase the illusions of control in successful executives and lead to overestimation or their ability to deal with liability of foreignness (Zaheer, 1995) issues and/or underestimation of the value of engaging with a local partner in order to gain access to local market knowledge. This may 
result in executives with international assignment experience opting for the highest degree of ownership and control in foreign operations, such as greenfield investments. Herman and Datta $(2002 ; 2006)$ found that CEOs with international experience are more likely to prefer full-control entry modes and will favor greenfield investments over acquisitions and joint ventures. International experiences are most likely to affect international strategic decision-making when several executives share international experience with the CEO (Jackson, 1992). If a large proportion of the executives have completed international assignments, they might share the same preferences for entry mode and be better able to communicate about, build consensus around, and implement greenfield investments without considering alternative options. Taken together, these arguments suggest that internationally experienced TMTs are more likely to engage in greenfield investments when expanding abroad (Herrmann \& Datta, 2006):

H2: TMT international experience increases the propensity to form greenfield investments abroad.

\subsection{Nationality diversity and foreign market entry}

In a team setting, differences in strategists' cognitive bases and values resulting from nationality diversity may reduce biases and positively affect their choice of alternatives. First, strategists with different cultural values and cognitions are likely to attend to different features of new problems when attempting to define them. Therefore, it is likely they will focus on different cues when selecting a problem-relevant schema (Schwenk, 1988). Second, given that executives choose to apply different schemas, they may consider different strategic alternatives and expect different consequences of these 
alternatives. Third, variation in cultural values among top manages will lead to preferences for different strategic actions (Hambrick \& Brandon, 1988). This may lead to debate or advocacy of different approaches to strategic decision-making and thus result in higher quality of decisions.

Cognitive diversity among upper echelons is often associated with conflicts or disagreements. While affective conflict among upper echelons was found to negatively influence decision quality, cognitive conflict is considered beneficial for strategic decision-making (Amason, 1996). When disagreements surrounding a particular decision occur, TMTs are aware of more issues, more ways of viewing each issue, and more alternative courses of action. If there are few or no cognitive conflicts, executives are less likely to consider a wide range of issues and options because they simply would not think of many of them (Miller, Burke \& Glick, 1998). In addition, when TMT members disagree they are more likely to invest in additional analysis, more consultants, and more discussions, which result in high extensiveness and comprehensiveness in decisionmaking. While such actions may slow-down executive decisions, the benefits of extensive analysis and evaluation of alternatives will ultimately result in better and more innovative strategic decisions. In general, scholars agree that cognitive conflict resulting from diversity contributes to decision quality because the synthesis that emerges from the contesting of the diverse perspectives is generally superior to the individual perspectives themselves (Mason \& Mitroff, 1981; Schwenk, 1990).

In the context of international decision-making, the varied perspectives and enriched debate that comes from TMT nationality diversity will be helpful in generating and refining alternatives (e.g. pertaining to different entry modes and selection of foreign 
partners). For instance, Watson et al. (1993) found that culturally diverse groups over time outperformed homogenous groups in range of perspectives and alternatives generated. McLeod, Lobel, and Cox (1996) also found that ideas generated by culturally diverse groups where of higher quality than the ideas produced by homogenous groups. TMTs with diverse national backgrounds are more likely to engage in constructive debate and thus may consider strategic choices other than greenfield investments, such as joint ventures and acquisitions, despite the higher complexity and cultural challenges associated with these entry modes. International acquisitions and JVs often face high costs and problems of integrating and managing a foreign partner that is often compounded by cultural and institutional differences. Nationally diverse TMTs possess the necessary cognitive capacity and skills to anticipate and manage such challenges.

International acquisitions and joint ventures are culturally complex international expansion decisions. Both types of entry modes are characterized by high failure rates (e.g., Beamish \& Delois, 1997; King et al., 2004) due, in part, to differences in objectives, management styles, operating methods, and strategy implementation as a result of cultural dissimilarities. Such differences are grounded in different assumptions about organizations, people, work, employment, performance, and reward systems in the societies involved (Von Glinow \& Teagarden, 1988).

IJVs entail unique risks, owing to the potential problems of cooperating with a partner from a different national culture (Harrigan, 1988). The cultural difference may create ambiguities in the relationship, which may lead to conflict and even dissolution of the venture (Barkema, Bell \& Pennings, 1996). IJVs are characterized by the presence of at least two cultures that interact and build interdependency. Success of an IJV relies on 
the creation of a coherent and unitary culture that combines elements of both. Top managers representing cultural partners in IJVs are instrumental in developing a shared culture as survival of IJVs is dependent on managing multiple meanings in the presence of national cultures (Li \& Hambrick, 2005). Culturally diverse TMTs are more likely to form such partnerships because their cognitive decision-making style is more open to the potential advantages of IJVs as a result of their own experiences working in a multicultural team. TMT nationality diversity may also provide reputational information to potential foreign partners that the firm has a global mindset, is easier to interact with in cross-culturally, and is more likely to adequately consider the foreign partners' interests. Such reputational effects may induce the foreign company itself to contact the focal firm and thus increases the potential pool of candidates and, cetera paribus, the probability of formation of IJVs (Lee \& Park, 2008):

H3: TMT nationality diversity increases the propensity to engage in international joint ventures

International acquisitions are often associated with cultural collision and postacquisition integration problems as a result of acquirer-target cultural distance (Datta \& Puia, 1995). Such cultural differences create organizational challenges that impede integration and increase acquisition costs (e.g., Hofstede, 1980). Higher levels of cultural distance have been associated with greater conflict in an acquisition over day-to-day decisions (Jemison \& Sitkin, 1986), and differences between parent and acquired firm can lead to culture clash among employees when operational practices also differ (Brock, 
Barry, \& Thomas, 2000). At the same time, cultural differences and the concept of psychic distance can inhibit and positively obstruct management attempts to integrate and create a cohesive and coherent organizational entity post acquisition. Constraints introduced by linguistic differences, multiple sources of authority, geographical distance, and cultural diversity are believed to make it more difficult to realize expected synergies in the foreign subsidiary than in a domestic strategic business unit (Gupta \& Govindarajan, 1991). Together these findings suggest that higher costs and complexity associated with cultural integration reduce post-acquisition performance.

Hambrick et al. (1998) suggested that nationality diversity influences not only the values and cognition but also the interpersonal dynamics of the TMTs members and ultimately decision-making outcomes. Hence, a TMT consisting of different nationalities is likely to be better equipped to handle the cultural complexity and constraints associated with international acquisitions because the application of culturally diverse cognitive schemas and heuristics helps reduce the uncertainty and increase the information processing capability. As Olie (1990) noted, the perceived threat of concentration and nationalism is a barrier to international acquisitions. However, a TMT composed of multiple nationalities is more likely to perceive international acquisitions more favorably compared to other forms of foreign investment modes (e.g., greenfield), which are preferred by internationally experienced TMTs. While international experience may create awareness of cross-cultural differences in general, it does not necessarily develop the ability in executives to cope with those in complex multicultural settings, such as international acquisitions. Whereas some aspects of global competence, such as knowledge and sensitivity to the challenges of working with foreign cultures, might be 
developed through international assignments, deeply rooted characteristics, such as flexibility, openness, and geocentrism cannot be developed through international assignments (e.g., Caligiuri \& DiSanto, 2001). Rather, diversity in top executives' cultural values and cognitions is likely to create the capacity to deal with challenges associated with cultural and institutional differences in international acquisitions. Thus, we propose that nationality diversity among TMT members affects positively the propensity to engage in international acquisitions:

H4: TMT nationality diversity increases the propensity to engage in international acquisitions.

\section{Methods}

\subsection{Sample and variables}

The initial sample consisted of all firms listed on the Swiss Stock Exchange in September 2004. Data was collected for 165 firms over a seven year period (2001-2007). Information on the characteristics of the TMT was obtained from company annual reports and websites. Firm and industry information was collected from the Worldscope database. Joint venture and acquisitions data was obtained from the Thomson SDC Platinum Database and the LexisNexis: Directory of Corporate Affiliations was used for information on greenfield investments.

Foreign expansion outside the home region was coded as 1 if an investment was made outside Europe, and 0 otherwise. International joint ventures is defined as a firm's propensity to engage in new entities created by the pooling of assets of two or more firms 
(Kogut \& Singh, 1988; Herrman \& Datta, 2006). Consistent with previous research we use the number of partnerships formed (Lee \& Park, 2008) with foreign firms in a particular year. Likewise, greenfield investments is measured as the number of new operations established in foreign countries by the parent company. International acquisitions is defined as the number of acquisitions of (existing) foreign firms announced in a particular year. We furthermore created entry mode dummy variables representing the three alternative modes. In addition, building on Brouthers and Hennart (2007) we created two separate dummies in order to control for level of ownership (acquisitions and greenfield investments are coded as 1 , and joint ventures as 0 ) and establishment mode (greenfield equals to 1 and acquisition equals to 0). Both sets of controls were used in the models where the individual entry mode decisions were used as the unit of analysis. As the results remained identical, we report the models with the level of ownership and establishment mode as controls.

The size of the firm has been previously shown to influence the propensity to engage in foreign expansions (Lee \& Park, 2008) and the mode selection (Brouthers \& Brouthers, 2003). Firm size was measured as the logarithm of firm employees. The level of prior international involvement is likely to influence subsequent internationalization decisions (Erramilli, 1991). We therefore controlled for international diversification using the entropy measure of firm diversification (Palepu, 1985), calculated with the formula $\Sigma \mathrm{P}_{\mathrm{i}} \ln \left(1 / \mathrm{P}_{\mathrm{i}}\right)^{2}$ where $\mathrm{P}$ is the percentage of segment sales of the total firm sales. We further included year dummies in order to control for temporal influences on executive strategic choices in the models where the number of foreign entries in a particular year were the dependent variables. As industry characteristics might influence 
the effects of TMTs (Hambrick \& Mason, 1984), we controlled for industry dynamism, which reflects the industry instability or volatility of the environment and was measured according to Dess and Beard (1984).

Nationality was recorded as the country of origin of the top executives as stated in the annual report. The degree of TMT nationality diversity was measured by the Blau index, a measure of group heterogeneity, which is commonly used in TMT research. The Blau index captures the dispersion of team members across all possible categories of a certain dimension using the formula $\mathrm{B}=\left[1-\Sigma\left(\mathrm{p}_{\mathrm{i}}\right)^{2}\right]$, where $\mathrm{p}$ is the percentage of members in the $\mathrm{i}^{\text {th }}$ group (i.e. nationality). The higher the value of $\mathrm{B}$, the greater is the heterogeneity on a particular variable. TMT international experience was measured as the percentage of TMT members with international work (assignment) experience (Carpenter et al, 2001). CEO international experience was measured as a dummy variable equal to one if the CEO had international work (assignment) experience from outside Switzerland and 0 otherwise. It was included as a control as previous research suggests that CEO international experience influences firm internationalization (Roth, 1995; Carpenter et al, 2001). We further included relevant TMT demographic diversity measures which were shown to influence strategic decision-making in a number of studies (for a review, see Cannella, Finkelstein \& Hambrick, 2008). TMT functional diversity and TMT educational diversity were calculated as the Blau index of individual top executives' current functions and educational backgrounds. Drawing on Wiersema and Bantel (1992), function was measured as a categorical variable with ten possible values: (1) production, (2) marketing and sales, (3) engineering, (4) finance and accounting, (5) general management, (6) R\&D, (7) legal, (8) human resources, (9) logistic, and (10) others. Education was coded 
in four main categories: (1) primary, (2) bachelor, (3) masters, and (4) $\mathrm{PhD}$. Industry experience diversity was measured as the proportion of TMT members with previous work experience in an industry different than the one in which the company operates. TMT size is another important aspect of TMT composition that has been shown to influence firm strategy (Carpenter et al., 2004). We therefore controlled for the number of TMT members.

\subsection{Analytical Strategy}

The research design resulted in a nested hierarchical structure, where international expansion decisions are nested within firms. Due to administrative heritage, prior experience and management practices, foreign expansion decisions within a firm are more likely to be similar than foreign expansions across different firms. It is therefore necessary to control for the lack of independence between multiple international expansions within firms over the seven year period. This created a hierarchical data structure with two levels of random variation: between international expansion decisions within firms (level 1), and between firms (level 2). Datasets with a nested structure that include unexplained variability at each level of nesting are usually not adequately represented by the probability model of ordinary least squares (OLS) regression analysis. Instead, a hierarchical linear model (HLM), which is an extension of multiple regression to a model that includes nested random coefficients, is recommended (Snijders \& Bosker, 1999; Raudenbush \& Bryk, 2002).

We used multilevel logistic regression to model the likelihood of a firm to expand outside its home region for each foreign entry decision. For the tests of the last three 
hypotheses, where the dependent variables are the number of IJVs, international acquisitions and greenfield investments in a particular year, we used multilevel Poisson regression, which is the appropriate technique for analyzing count data.

\section{Results}

Table 1 provides means, standard deviations, and correlations for all variables. The companies in our sample engaged in 190 international joint-ventures, 502 international acquisitions and 712 greenfield investments over the seven year period (2001-2007).

Insert Table 1 about here

In support of hypotheses 1 , we found that the diversity in TMT nationality diversity was positively related to the likelihood of expanding outside the home region $(b=.88, p$ $<.05)$. International experience was also found to increase the likelihood of expanding outside the home region $(b=.73, p<.05)$. Our results further suggest that companies are more likely to use joint ventures $(b=-1.53, p<.001)$ and prefer greenfield investments over acquisitions $(\mathrm{b}=.43, \mathrm{p}<.01)$ when expanding outside the home region (see table 2$)$.

Insert Table 2 about here

Furthermore, in support of hypothesis 2 (see Model 1 in Table 3), we found that TMT international experience is positively associated with the propensity to establish greenfield subsidiaries $(\mathrm{b}=.85, \mathrm{p}<.05)$. Hypothesis 3 , suggesting that nationally diverse TMTs are more likely to form international joint ventures, was also supported $(b=2.66$, $\mathrm{p}<.01)$ (see Model 2 in Table 3). Finally, hypothesis 4 was supported. The results (see Model 3 in Table 3) show that TMT nationality diversity was positively associated with 
the propensity to undertake international acquisitions $(b=.82, p<.05)$. Interestingly, our results further suggest that nationality diversity reduces the propensity to make greenfield investments $(\mathrm{b}=-1.58, \mathrm{p}<.01)$ (see Model 1 in Table 3$)$.

Insert Table 3 about here

Together, these results lend support to the importance of distinguishing between international experience and nationality diversity in studies of executive effects on international strategic decision-making.

\section{Discussion}

Despite the upward trend of hiring foreign nationals in the upper echelons of large corporations and the anticipated benefits in times of increasing globalization, the effects of TMT nationality diversity on strategic decision-making have remained largely unexplored. Thus, the first contribution of our study was to establish the validity of nationality diversity as an important TMT diversity dimension. As evidenced by our theoretical model and empirical results, nationality diversity differs from other TMT diversity attributes, such as international experience, functional or educational diversity, lending support to the value-added of accounting for it in studies of TMT diversity. Specifically, our study confirms that TMT nationality diversity and international experience are two related yet distinct characteristics influencing international strategic decision-making. We find that nationality diversity positively influences the propensity to expand outside the home region even after controlling for TMT international experience. This suggests that while international experience may provide valuable knowledge and 
network contacts, nationality diversity brings additional benefits which cannot be acquired through international assignments. Such benefits arise from the variety of values and cognitive schemas deeply rooted in individual's national culture. These results are consistent with Geletkanycz's (1997) findings that both prior experiences and cultural socialization contribute to the shaping of executives' strategic mindset. However, top decision-makers remain deeply rooted in their own cultures and their strategic mindset is to a large degree shaped by their nationality (Caligiuri \& DeSanto, 2001). It appears that executives' cultural identity is not lost over time, nor is it overshadowed by professional acculturation associated with firm or industry experience. Rather, the values embedded in national cultures seem to have a profound and enduring effect on executives' orientations, independent of the logics and wisdom accrued in management development.

Another contribution of our study is the simultaneous consideration of rational factors and TMT characteristics in relation to international strategic decision-making. Consistent with the international business literature, we find that the degree of ownership and establishment mode are likely to influence international expansion. At the same time, however, we also find that characteristics of the TMT play an important and distinct role. This combination of the behavioral theory of internationalization with the upper echelons perspective may help advance our knowledge regarding managerial decision making in international business. Our results suggest that TMT nationality diversity can be an important mechanism to overcome the natural tendency toward regionalism. Foreign expansion outside a firms' home region is associated with increased costs of liability of foreignness and risks of investments. Whereas Rugman and Verbeke (2004:16) explained the tendency to expand intra-regionally as the result of a rational cost-benefit analysis 
based on the "cost of inter-regional distance and liability of inter-regional foreignness", we argue that such decisions may have a behavioral component. Whereas nationally homogenous TMTs may be more inclined to stay within the home region, nationality diversity provides managerial resources that encourage extra-regional expansion.

This study further demonstrates that nationality diversity and international experience exert distinct impact on international strategic decision-making. While both international experience and nationality diversity exert positive influence on firms' propensity to expand outside their home region, we discern the different effects of international experience and nationality diversity on the propensity to use specific entry modes in internationalization. We find that heterogeneity in national cultural composition of the TMT increases the likelihood of using culturally complex foreign entry modes. Specifically, we find that while international experience is positively associated with the propensity to enter new markets via greenfield investments, nationality diversity is positively related to international acquisitions and JVs.

These results point to the value of studying various aspects of managerial backgrounds in international strategic decision-making. It seems that nationally diverse TMTs are endowed with culturally diverse values and cognitive structures that lead them to a stronger preference for culturally complex and uncertain entry modes than do TMTs with international experiences. The diverse national backgrounds may lead to constructive debate and cognitive conflict, which is likely to affect scanning, selection, and interpretation of relevant information, in turn, influencing perceptions of uncertainty and costs associated with strategic choices. Hence, despite the seemingly higher barriers associated with "double layered acculturation" (Barkema et al., 1996) of international 
JVs and acquisitions, nationally diverse TMTs might feel confident in their ability to integrate and manage a foreign partner. These findings may lend some support to the behavioral theory of internationalization in that it emphasizes bounded rational managerial decision-making rather than economically based rational choice.

To the extent that nationality diversity and international experience both represent valuable managerial characteristics in relation to international strategic decision-making they may reinforce each other. However, the interaction effect between these two variables (not reported here) was not significant, indicating that the combined effect does not explain managerial decision-making in relation to foreign entry modes. Rather, it seems that international experience and nationality diversity represent two independent strategic decision-making resources in terms of firm internationalization. Interestingly, our results also revealed a negative relationship between nationality diversity and greenfield investments. While we did not test explicitly for the choice between different entry modes as a result of TMT characteristics, this results may indicate such a tradeoff. Future research may seek to tease out the influence of nationality diversity on entry mode and establishment chain choices.

While this study focused on TMT nationality diversity, future studies may seek to explore the effects of TMT cultural composition. Researchers may investigate how Hofstede's national cultural dimensions influence international strategic decisions. For instance, the average uncertainty avoidance at the TMT level may impact the propensity to expand abroad or the choice of entry mode. In the past TMTs were culturally homogenous and shared the same cultural attributes as the home country, however, the increasing diversity leads to intra-country variation of TMT cultural characteristics. 
While such cultural diversity brings benefits to TMT decision-making, it also creates certain challenges and future research may investigate how faultlines (Lau \& Murnighan, 1998) emerge based on the individual level Hofstede national culture scores.

Finally, our study has some implications for practitioners. While nationality may not be among the primary selection criteria for TMT members, this study demonstrated its strong influence on international strategic decision-making. For executive selection this means that it is important to pay attention not only to international assignment experience but also to the national composition of the TMT. Moreover, awareness of the potential biases due to individual backgrounds and experiences can help reduce the negative effects of such biases in international strategic decision-making. Understanding and attending to their own predispositions - as well as those of the other TMT members top managers may be better able to balance rational motives with their own strategic orientation. 


\section{References}

Amason, A.C. (1996). Distinguishing the effects of functional and dysfunctional conflict

on strategic decision making: Resolving a paradox for top management teams, Academy of Management Journal, 39: 123-148.

Anderson, E., \& Gatignon, H. (1986). Modes of foreign entry: A transaction cost analysis and propositions, Journal of International Business Studies, 17: 1-26.

Athanassiou N. \& Nigh D. (2002). The impact of the top management team's international business experience on the firm's internationalization: Social networks at work, Management International Review, 42: 157-181.

Barkema, H.G., Bell, J.H.J. \& Pennings, J.M. (1996). Foreign entry, cultural barriers, and learning, Strategic Management Journal, 17: 151-166.

Bartlett, C., \& Ghoshal, S. (1989). Managing across borders. Boston: HBS Press.

Beamish, P.W. \& Delois, A. (1997). Joint ventures in LDC's: Partner selection and performance, Management International Review, 34: 60-74.

Benito, G.R.G \& Gripsrud, G. (1992). The expansion of foreign direct investments: Discrete rational location choices or a cultural learning process?, Journal of International Business Studies, 23(3): 461-476.

Brock, D.M., Barry, D. \& Thomas, D.C. (2000). "Your forward is our reverse, your right, our wrong": rethinking multinational planning processes in light of national culture, International Business Review, 9(6): 687-701.

Brouthers, K.D.\& Hennart, J-F. (2007). Boundaries of the firm: Insights from international entry mode research, Journal of Management, 33(3): 395-425. 
Caligiuri, P.M. \& DeSanto, V. (2001). Global competence: What is it, and can it be developed through global assignments? Human Resource Planning Journal, 24: 27-38. Caligiuri, P.M., Lazarova, M. \& Zehetbauer, S. (2004). Top managers' national diversity and boundary spanning, Journal of Management Development, 23(9): 848-859.

Carpenter, M.A., Geletkanycz, M.A., \& Sanders, W.G. (2004). Upper echelons research revisited: Antecedents, elements, and consequences of top management team composition. Journal of Management, 30(6): 747-778.

Carpenter, M.A., Sanders, W.G., \& Gregersen, H.B. (2001). Bundling human capital with organizational context: The impact of international assignment experience on multinational firm performance and CEO pay, Academy of Management Journal, 44: 493-511.

Cyert, R.M. \& March, J.A. (1963). A Behavioural Theory of the Firm. Englewood Cliffs: Prentice-Hall.

Daily, C.M., Certo, S.T., \& Dalton, D.R. (2000). International experience in the executive suite: The path to prosperity, Strategic Management Journal, 21: 515-523.

Datta, D. K. \& Puia, G. (1995). Cross-border acquisitions: An examination of the influence of relatedness and cultural fit on shareholder value creation in U.S. acquiring firms, Management International Review, 35: 337-359.

Dess, G.G., \& Beard D. W. (1984). Dimensions of organizational task environments. Administrative Science Quarterly, 29: 52-73.

Duhaime, I.M., \& Schwenk, C.R. (1985). Conjectures on cognitive simplification in acquisition and divestment decision making, Academy of Management Review, 10(2): 287-295. 
Dutton J. E., Fahey L. \& Narayanan V. K. (1983). Towards understanding strategic issue diagnosis, Strategic Management Journal, 4 (4): 307-323.

Eisenhardt, K.M., \& Schoonhoven, C.B. (1996). Resource based view of strategic alliance formation: Strategic and social effects in entrepreneurial firms, Organization Science, 7: 136-150.

Erramilli, M. K. (1991). The experience factor in foreign market entry behavior of service firms, Journal of International Business Studies, 22(3): 479-501.

Ferrier, W.J. (2001). Navigating the competitive landscape: The drivers and consequences of competitive aggressiveness. Academy of Management Journal, 44: 858 877.

Finkelstein, S., Hambrick, D.C., \& Cannella, A.A. (2008). Strategic Leadership: Theory and research on executives, top management teams, and boards, Oxford University press, NY: New York.

Geletkanycz, M.A. (1997). The salience of "culture's consequences": The effects of cultural values on executive commitment to the status quo. Strategic Management Journal, 18(8): 615-634.

Gupta, A., \& Govindarajan, V. (1991). Knowledge flows and the structure of control within multinational corporations, Academy of Management Review, 16: 768-792.

Gupta, A., \& Govindarajan, V. (2002). Cultivating a global mindset. Academy of Management Executive, 16(1): 116-126

Hambrick. D.C., \& Brandon, G.L. (1988). Executive values, In Hambrick, D.C. (Ed.) The executive effect: Concepts and methods for studying top managers, JAI Press, Inc. Greenwich, Connecticut: 3-34. 
Hambrick, D.C., \& Mason, P.A. (1984). Upper echelons: The organization as a reflection of its top managers. Academy of Management Review, 9: 193-206.

Hambrick, D.C., Davidson, S.C., Snell, S.A., \& Snow, C.C. (1998). When groups consists of multiple nationalities: Towards a new understanding of the implications, Organization Studies, 19(2): 181-205.

Harrigan, K.R. (1988). Joint Ventures and Competitive Strategy, Strategic Management Journal, 9: 141-158.

Hennart, J.F. (1988). A transaction costs theory of equity joint ventures, Strategic Management Journal, 9: 361-374.

Hennart, J.F. \& Larimo, J. (1998) The impact of culture on the strategy of multinational enterprises: does national origin affect ownership decisions? Journal of International Business Studies, 29: 515-538.

Hennart, J.F., \& Park,Y.R. (1993). Greenfield vs. acquisition: The strategy of Japanese investors in the United States, Management Science, 39(9): 1054-1070.

Herrmann, P. \& Datta, D.K. (2002). CEO successor characteristics and the choice of foreign market entry mode: An empirical study, Journal of International Business Studies, 33(3): 551-569

Herrmann, P. \& Datta, D.K. (2005). Relationships between top management team characteristics and international diversification: An empirical investigation, British Journal of Management, 16: 69-78.

Herrmann, P., \& Datta, D. K. (2006). CEO experiences: Effects on the choice of FDI entry mode, Journal of Management Studies, 43(4): 755-778. 
Hitt, M., Dacin, T., Tyler, B. \& Park, D. (1997). Understanding the differences in Korean and U.S. executives' strategic orientations, Strategic Management Journal, 18: 159-167. Hofstede, G. (1980). Culture’s consequences, Newburry Park, CA: Sage.

Hofstede, G., \& Hofstede, G.J. (2005). Cultures and organizations: Software of the mind, McGraw-Hill, NY: New York.

Jemison, D.B. \& Sitkin, S.B. (1986). Corporate acquisitions : A process perspective, Academy of Management Review, 11: 145-163.

Jensen, M., \& Zajac, E., (2004). Corporate elites and corporate strategy: How demographic preferences and structural position shape the scope of the firm, Strategic Management Journal, 25(6): 507-524.

Johanson, J., \& Vahlne, J.-E. (1977). The internationalization process of the firm: A model of knowledge development and increasing foreign market commitments. Journal of International Business Studies, 8(1), 23-32.

Johanson, J. \& Wiedersheim-Paul, F. (1975). The internationalisation of the firm: Four Swedish case studies, Journal of Management Studies, 12,: 305-322.

King, D.R., Dalton, D.R., Daily, C.M., \& Kovin, J.G. (2004). Meta-analyses of postacquisition performance: Indications of unidentified moderators, Strategic Management Journal, 25: 187-200.

Kogut, B \& Singh, H (1988). The effect of national culture on the choice of entry mode, Journal of International Business Studies, 19: 411-432.

Lau, D. C. \& Murnighan J. K. (1998). Demographic diversity and faultlines: The compositional dynamics of organizational groups, Academy of Management Review, 23: $325-340$. 
Laurent, A. (1983). The cultural diversity of Western conceptions of management, International Studies of Management and Organizations, 13: 75-96.

Lee, H.U., \& Park, J.H. (2008). The influence of top management team international exposure on international alliance formation, Journal of Management Studies, 45:961981.

Luo, Y. (2005). How does globalization affect corporate governance and accountability? A perspective from MNEs, Journal of International Management, 11: 19-41.

Mason, I., \& Mitroff, I. (1981). Challenging strategic planning assumptions, New York: Wiley.

March, J.G. \& Simon, H.A. (1958). Organizations, N.Y.: Wiley.

McLeod, P.L., Lobel, S.A., \& Cox, T.H. (1996). Ethnic diversity and creativity in small groups, Small Group Research, 27(2): 248-264.

Miller C. C, Burke L. M. \& Glick W.H. (1998). Cognitive diversity among upper-echelon executives: Implications for strategic decision processes, Strategic Management Journal, 19: $39-58$.

Olie, R. (1990). Culture and integration problems in international mergers and acquisitions, European Management Journal, 8(2): 206-215.

Palepu, K. (1985). Diversification strategy, profit performance and the entropy measure. Strategic Management Journal, 6(3): 239-255.

Prahalad, C. \& Bettis, R. (1986). The dominant logic: A new linkage between diversity and performance, Strategic Management Journal, 7: 485-501.

Punnett, B.J., \& Clemens, J. (1999). Cross-national diversity: implications for international expansion decisions, Journal of World Business, 34(2): 167-177. 
Reuber, R.A., \& Fischer, E. (1997). The influence of top management team's international experience on the internationalization behaviors of SMEs, Journal of International Business Studies, 28: 807-825.

Roth, K. (1995). Managing international interdependence: CEO characteristics in a resource based framework, Academy of Management Journal, 38: 200-231.

Rugman, A \& Verbeke, A. (2004). A perspective on regional and global strategies of multinational enterprises, Journal of International Business Studies, 35: 3-18.

Sambharya, R. B. (1996). Foreign experience of top management teams and international diversification strategies of U.S. multinational corporations. Strategic Management Journal, 17: 739-746.

Sanders, W.G. \& Carpenter, M.A. (1998). Internationalization and firm governance: The roles of CEO compensation, top team composition and board structure, Academy of Management Journal, 41: 158-178.

Schwartz, S. H. (1992). Universals in the content and structure of values: Theoretical advances and empirical tests in 20 countries. In M. P. Zanna (Ed.), Advances in experimental social psychology: 1-65. San Diego, CA: Academic Press.

Schwenk, C. (1988). The cognitive perspective on strategic decision making, Journal of Management Studies, 25(1): 41-55.

Schwenk, C. (1990). Effects of devil's advocacy and dialectical inquiry on decision making: A meta-analysis, Organizational Behavior and Human Decision Processes,47(1): 161-176.

Shane, S., Venkataraman, S. \& MacMillan, I. (1995). Cultural differences in innovation championing strategies, Journal of Management, 21: 931-952. 
Shaw, J.B. (1990). A cognitive categorization model for the study of cultural management, Academy of Management Review, 15(4): 626-645.

Starbuck, W.H., \& Milliken, F.J. (1988). Executives' perceptual filters: What they notice and how they make sense, In Hambrick, D.C. (Ed.) The executive effect: Concepts and methods for studying top managers, JAI Press, Inc. Greenwich, Connecticut: 35-66.

Sutton R. I. (1987). The process of organizational death: Disbanding and reconnecting, Administrative Science Quarterly, 32: 42-569.

Tihanyi, L., Ellstrand, A.E., Daily, C.M., \& Dalton, D.R. (2000). Composition of the top management team and Firm International Diversification. Journal of Management, 26(6): 1157-1177.

Tung, R. L., Miller, E. L. (1990). Managing in the twenty-first century: The need for global orientation, Management International Review, 30(1): 5-18.

Tversky, A., \& Kahneman, D. (1974). Judgment under uncertainty: Heuristics and biases, Science, 185: 1124-1131.

Von Glinow, M.A. \& Teagarden, M.B. (1988). The transfer of human resource management technology in Sino-U.S. cooperative ventures: Problems and solutions, Human Resource Management, 27(2): 201-229.

Wally S. \& Becerra M. (2001). Top management team characteristics and strategic changes in international diversification, Group \& Organization Management, 26 (2): 165-188.

Walsh, J.P. (1995). Managerial and organizational cognition: Notes from a trip down memory lane, Organization Science, 6(3): 280-321. 
Watson, W.E., Kumar, K., \& Michaelsen, L.K. (1993). Cultural diversity's impact on interaction process and performance: Comparing homogeneous and diverse task groups. Academy of Management Journal, 36: 590-602.

Wiersema, M., \& Bantel, K. (1992). Top management team demography and corporate strategic change. Academy of Management Journal, 35: 91-121.

Williamson, O. E. (1985). The economic institutions of capitalism New York: Basic Books.

Zaheer, S. (1995). Overcoming the liability of foreignness. Academy of Management Journal, 38(2): 341-363. 
Table 1. Means, standard deviations and means

\begin{tabular}{|c|c|c|c|c|c|c|c|c|c|c|c|c|c|c|c|c|}
\hline & Variable & Mean & S.D. & 1 & 2 & 3 & 4 & 5 & 6 & 7 & 8 & 9 & 10 & 11 & 12 & 13 \\
\hline 1 & Firm size & 8.66 & 1.61 & 1.00 & & & & & & & & & & & & \\
\hline 2 & Firm internationalization & 1.13 & 0.44 & 0.52 & 1.00 & & & & & & & & & & & \\
\hline 3 & Industry dynamism & 0.03 & 0.04 & 0.12 & -0.03 & 1.00 & & & & & & & & & & \\
\hline 4 & CEO international experience & 0.39 & 0.49 & 0.19 & 0.17 & -0.07 & 1.00 & & & & & & & & & \\
\hline 5 & TMT size & 6.59 & 2.88 & 0.41 & 0.28 & 0.12 & 0.05 & 1.00 & & & & & & & & \\
\hline 6 & TMT industry experience & 0.38 & 0.31 & -0.04 & -0.08 & 0.04 & -0.01 & 0.01 & 1.00 & & & & & & & \\
\hline 7 & TMT educational diversity & 0.45 & 0.25 & 0.04 & -0.02 & 0.03 & 0.07 & 0.21 & 0.15 & 1.00 & & & & & & \\
\hline 8 & TMT functional diversity & 0.57 & 0.19 & 0.05 & 0.11 & -0.01 & 0.02 & 0.26 & 0.11 & 0.10 & 1.00 & & & & & \\
\hline 9 & TMT international experience & 0.31 & 0.31 & 0.26 & 0.23 & -0.03 & 0.29 & 0.13 & -0.09 & -0.06 & 0.01 & 1.00 & & & & \\
\hline 10 & TMT nationality diversity & 0.42 & 0.27 & 0.39 & 0.39 & -0.03 & 0.20 & 0.45 & -0.06 & -0.01 & 0.11 & 0.30 & 1.00 & & & \\
\hline 11 & Number of IJVs & 0.18 & 0.83 & 0.29 & 0.11 & 0.05 & 0.12 & 0.16 & -0.02 & 0.00 & 0.07 & 0.08 & 0.17 & 1.00 & & \\
\hline 12 & Number of int. acquisitions & 0.72 & 1.36 & 0.45 & 0.28 & 0.08 & 0.11 & 0.25 & -0.02 & 0.01 & -0.02 & 0.14 & 0.25 & 0.27 & 1.00 & \\
\hline 13 & Number of greenfields & 1.51 & 4.08 & 0.37 & 0.18 & 0.15 & 0.10 & 0.18 & -0.08 & 0.10 & 0.01 & 0.13 & 0.20 & 0.15 & 0.26 & 1.00 \\
\hline
\end{tabular}

$\mathrm{N}=1404$ foreign entry decisions in 165 firms 
Table 2. Results of logistic HLM analysis:

The effects of TMT characteristics on the likelihood of expanding outside the home region

\begin{tabular}{|lcc|}
\hline \multicolumn{1}{|c}{ Variable } & Coefficient & SE \\
\hline Intercept & $0.90 * \star \star$ & 0.25 \\
Firm size & 0.00 & 0.09 \\
Firm internationalization & 0.50 & 0.34 \\
Industry dynamism & 1.07 & 3.57 \\
CEO international experience & 0.35 & 0.20 \\
TMT size & 0.03 & 0.03 \\
TMT industry experience & -0.22 & 0.35 \\
TMT educational diversity & -0.16 & 0.36 \\
TMT functional diversity & -0.77 & 0.46 \\
TMT international experience & $0.73 *$ & 0.35 \\
TMT nationality diversity & $0.88 *$ & 0.42 \\
Level of ownership & $-1.53 * \star *$ & 0.21 \\
Establishment mode & $0.43 * *$ & 0.14 \\
\hline$* * * \mathrm{p}<001, * * \mathrm{p}<01,{ }^{*}<.05$ & &
\end{tabular}


Table 3. Results of Poisson HLM analysis:

The effects of TMT characteristics on the propensity to engage in different entry modes

\begin{tabular}{|c|c|c|c|c|c|c|c|c|c|}
\hline \multirow[b]{3}{*}{ Firm size } & \multicolumn{3}{|c|}{$\begin{array}{c}\text { Greenfield investments } \\
\text { Model } 1(\mathrm{H} 2) \\
\end{array}$} & \multicolumn{3}{|c|}{$\begin{array}{c}\text { IJVs } \\
\text { Model } 2(\mathrm{H} 3) \\
\end{array}$} & \multicolumn{3}{|c|}{$\begin{array}{c}\text { International acquisitions } \\
\text { Model } 3(\mathrm{H} 4) \\
\end{array}$} \\
\hline & \multicolumn{2}{|c|}{ Coefficient } & \multirow{2}{*}{$\frac{\text { S.E. }}{0.15}$} & \multicolumn{2}{|c|}{ Coefficient } & \multirow{2}{*}{$\frac{\text { S.E. }}{0.16}$} & \multicolumn{2}{|c|}{ Coefficient } & \multirow{2}{*}{$\frac{\text { S.E. }}{0.07}$} \\
\hline & 0.67 & $\star \star \star$ & & 0.79 & $\star \star \star *$ & & 0.62 & $\star \star *$ & \\
\hline Firm internationalization & -0.12 & & 0.41 & -0.15 & & 0.49 & 0.29 & & 0.21 \\
\hline Industry dynamism & 3.72 & & 4.77 & 0.91 & & 7.61 & -1.05 & & 3.38 \\
\hline TMT size & 0.02 & & 0.02 & 0.05 & & 0.06 & -0.01 & & 0.03 \\
\hline TMT industry experience & -1.35 & $\star \star$ & 0.48 & 0.56 & & 0.71 & 0.41 & & 0.27 \\
\hline TMT educational diversity & 0.01 & & 0.43 & -0.02 & & 0.88 & 0.34 & & 0.36 \\
\hline TMT functional diversity & 0.00 & & 0.50 & 0.94 & & 0.98 & -0.31 & & 0.38 \\
\hline CEO international experience & 0.22 & & 0.22 & 0.33 & & 0.43 & -0.26 & & 0.19 \\
\hline TMT international experience & 0.85 & * & 0.42 & -1.33 & & 0.84 & -0.27 & & 0.33 \\
\hline TMT nationality diversity & -1.58 & $\star \star$ & 0.57 & 2.66 & $\star \star$ & 1.02 & 0.82 & * & 0.37 \\
\hline Year 2002 & -20.82 & & 61.09 & 0.25 & & 0.45 & 0.14 & & 0.23 \\
\hline Year 2003 & -0.52 & $\star \star$ & 0.15 & 0.07 & & 0.46 & -0.36 & & 0.24 \\
\hline Year 2004 & -0.38 & * & 0.16 & -0.46 & & 0.53 & 0.05 & & 0.22 \\
\hline Year 2005 & -1.89 & $\star \star \star *$ & 0.23 & 0.24 & & 0.48 & -0.10 & & 0.23 \\
\hline Year 2006 & -0.70 & $\star \star \star$ & 0.17 & 0.58 & & 0.46 & 0.20 & & 0.22 \\
\hline Year 2007 & -1.32 & $\star * \star$ & 0.19 & 0.55 & & 0.46 & 0.12 & & 0.22 \\
\hline Intercept & -4.42 & $\star \star$ & 1.29 & -11.49 & 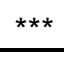 & 1.69 & -6.67 & 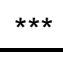 & 0.70 \\
\hline Deviance & 974.284 & & & 325.26 & & & 940.08 & & \\
\hline Wald Chi ${ }^{2}$ & 160.17 & $\star \star *$ & & 57.72 & $\star \star \star *$ & & 156.38 & 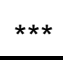 & \\
\hline
\end{tabular}




\section{SMG - Working Papers \\ www.cbs.dk/smg \\ 2003}

2003-1: Nicolai J. Foss, Kenneth Husted, Snejina Michailova, and Torben Pedersen: Governing Knowledge Processes: Theoretical Foundations and Research Opportunities.

2003-2: Yves Doz, Nicolai J. Foss, Stefanie Lenway, Marjorie Lyles, Silvia Massini, Thomas P. Murtha and Torben Pedersen: Future Frontiers in International Management Research: Innovation, Knowledge Creation, and Change in Multinational Companies.

2003-3: Snejina Michailova and Kate Hutchings: The Impact of In-Groups and OutGroups on Knowledge Sharing in Russia and China CKG Working Paper.

2003-4: Nicolai J. Foss and Torben Pedersen: The MNC as a Knowledge Structure: The Roles of Knowledge Sources and Organizational Instruments in MNC Knowledge Management CKG Working Paper.

2003-5: Kirsten Foss, Nicolai J. Foss and Xosé H. Vázquez-Vicente: “Tying the Manager's Hands": How Firms Can Make Credible Commitments That Make Opportunistic Managerial Intervention Less Likely CKG Working Paper.

2003-6: Marjorie Lyles, Torben Pedersen and Bent Petersen: Knowledge Gaps: The Case of Knowledge about Foreign Entry.

2003-7: Kirsten Foss and Nicolai J. Foss: The Limits to Designed Orders: Authority under "Distributed Knowledge" CKG Working Paper.

2003-8: Jens Gammelgaard and Torben Pedersen: Internal versus External Knowledge Sourcing of Subsidiaries - An Organizational Trade-Off.

2003-9: Kate Hutchings and Snejina Michailova: Facilitating Knowledge Sharing in Russian and Chinese Subsidiaries: The Importance of Groups and Personal Networks Accepted for publication in Journal of Knowledge Management.

2003-10: Volker Mahnke, Torben Pedersen and Markus Verzin: The Impact of Knowledge Management on MNC Subsidiary Performance: the Role of Absorptive Capacity CKG Working Paper.

2003-11: Tomas Hellström and Kenneth Husted: Mapping Knowledge and Intellectual Capital in Academic Environments: A Focus Group Study Accepted for publication in Journal of Intellectual Capital CKG Working Paper.

2003-12: Nicolai J Foss: Cognition and Motivation in the Theory of the Firm: Interaction or "Never the Twain Shall Meet"? Accepted for publication in Journal des Economistes et des Etudes Humaines CKG Working Paper.

2003-13: Dana Minbaeva and Snejina Michailova: Knowledge Transfer and Expatriation Practices in MNCs: The Role of Disseminative Capacity.

2003-14: Christian Vintergaard and Kenneth Husted: Enhancing Selective Capacity Through Venture Bases. 


\section{4}

2004-1: Nicolai J. Foss: Knowledge and Organization in the Theory of the Multinational Corporation: Some Foundational Issues

2004-2: Dana B. Minbaeva: HRM Practices and MNC Knowledge Transfer

2004-3: Bo Bernhard Nielsen and Snejina Michailova: Toward a Phase-Model of Global Knowledge Management Systems in Multinational Corporations

2004-4: Kirsten Foss \& Nicolai J Foss: The Next Step in the Evolution of the RBV: Integration with Transaction Cost Economics

2004-5: Teppo Felin \& Nicolai J. Foss: Methodological Individualism and the Organizational Capabilities Approach

2004-6: Jens Gammelgaard, Kenneth Husted, Snejina Michailova: Knowledge-sharing Behavior and Post-acquisition Integration Failure

2004-7: Jens Gammelgaard: Multinational Exploration of Acquired R\&D Activities

2004-8: Christoph Dörrenbächer \& Jens Gammelgaard: Subsidiary Upgrading? Strategic Inertia in the Development of German-owned Subsidiaries in Hungary

2004-9: Kirsten Foss \& Nicolai J. Foss: Resources and Transaction Costs: How the Economics of Property Rights Furthers the Resource-based View

2004-10: Jens Gammelgaard \& Thomas Ritter: The Knowledge Retrieval Matrix: Codification and Personification as Separate Strategies

2004-11: Nicolai J. Foss \& Peter G. Klein: Entrepreneurship and the Economic Theory of the Firm: Any Gains from Trade?

2004-12: Akshey Gupta \& Snejina Michailova: Knowledge Sharing in Knowledge-Intensive Firms: Opportunities and Limitations of Knowledge Codification

2004-13: Snejina Michailova \& Kate Hutchings: Knowledge Sharing and National Culture: A Comparison Between China and Russia

\section{5}

2005-1: Keld Laursen \& Ammon Salter: My Precious - The Role of Appropriability Strategies in Shaping Innovative Performance

2005-2: Nicolai J. Foss \& Peter G. Klein: The Theory of the Firm and Its Critics: A Stocktaking and Assessment

2005-3: Lars Bo Jeppesen \& Lars Frederiksen: Why Firm-Established User Communities Work for Innovation: The Personal Attributes of Innovative Users in the Case of Computer-Controlled Music

2005-4: Dana B. Minbaeva: Negative Impact of HRM Complementarity on Knowledge Transfer in MNCs

2005-5: Kirsten Foss, Nicolai J. Foss, Peter G. Klein \& Sandra K. Klein: Austrian Capital 
Theory and the Link Between Entrepreneurship and the Theory of the Firm

2005-1: Nicolai J. Foss: The Knowledge Governance Approach

2005-2: Torben J. Andersen: Capital Structure, Environmental Dynamism, Innovation Strategy, and Strategic Risk Management

2005-3: Torben J. Andersen: A Strategic Risk Management Framework for Multinational Enterprise

2005-4: Peter Holdt Christensen: Facilitating Knowledge Sharing: A Conceptual Framework

2005-5 Kirsten Foss \& Nicolai J. Foss: Hands Off! How Organizational Design Can Make Delegation Credible

2005-6 Marjorie A. Lyles, Torben Pedersen \& Bent Petersen: Closing the Knowledge Gap in Foreign Markets - A Learning Perspective

2005-7 Christian Geisler Asmussen, Torben Pedersen \& Bent Petersen: How do we Capture "Global Specialization" when Measuring Firms' Degree of internationalization?

2005-8 Kirsten Foss \& Nicolai J. Foss: Simon on Problem-Solving: Implications for New Organizational Forms

2005-9 Birgitte Grøgaard, Carmine Gioia \& Gabriel R.G. Benito: An Empirical Investigation of the Role of Industry Factors in the Internationalization Patterns of Firms

2005-10 Torben J. Andersen: The Performance and Risk Management Implications of Multinationality: An Industry Perspective

2005-11 Nicolai J. Foss: The Scientific Progress in Strategic Management: The case of the Resource-based view

2005-12 Koen H. Heimeriks: Alliance Capability as a Mediator Between Experience and Alliance Performance: An Empirical Investigation Into the Alliance Capability Development Process

2005-13 Koen H. Heimeriks, Geert Duysters \& Wim Vanhaverbeke: Developing Alliance Capabilities: An Empirical Study

2005-14 JC Spender: Management, Rational or Creative? A Knowledge-Based Discussion

\section{6}

2006-1: Nicolai J. Foss \& Peter G. Klein: The Emergence of the Modern Theory of the Firm

2006-2: Teppo Felin \& Nicolai J. Foss: Individuals and Organizations: Thoughts on a Micro-Foundations Project for Strategic Management and Organizational Analysis

2006-3: Volker Mahnke, Torben Pedersen \& Markus Venzin: Does Knowledge Sharing 
Pay? An MNC Subsidiary Perspective on Knowledge Outflows

2006-4: Torben Pedersen: Determining Factors of Subsidiary Development

2006-5 Ibuki Ishikawa: The Source of Competitive Advantage and Entrepreneurial Judgment in the RBV: Insights from the Austrian School Perspective

2006-6 Nicolai J. Foss \& Ibuki Ishikawa: Towards a Dynamic Resource-Based View: Insights from Austrian Capital and Entrepreneurship Theory

2006-7 Kirsten Foss \& Nicolai J. Foss: Entrepreneurship, Transaction Costs, and Resource Attributes

2006-8 Kirsten Foss, Nicolai J. Foss \& Peter G. Klein: Original and Derived Judgement: An Entrepreneurial Theory of Economic Organization

2006-9 Mia Reinholt: No More Polarization, Please! Towards a More Nuanced Perspective on Motivation in Organizations

2006-10 Angelika Lindstrand, Sara Melen \& Emilia Rovira: Turning social capital into business? A study of Swedish biotech firms' international expansion

2006-11 Christian Geisler Asmussen, Torben Pedersen \& Charles Dhanaraj: Evolution of Subsidiary Competences: Extending the Diamond Network Model

2006-12 John Holt, William R. Purcell, Sidney J. Gray \& Torben Pedersen: Decision Factors Influencing MNEs Regional Headquarters Location Selection Strategies

2006-13 Peter Maskell, Torben Pedersen, Bent Petersen \& Jens Dick-Nielsen: Learning Paths to Offshore Outsourcing - From Cost Reduction to Knowledge Seeking

2006-14 Christian Geisler Asmussen: Local, Regional or Global? Quantifying MNC Geographic Scope

2006-15 Christian Bjørnskov \& Nicolai J. Foss: Economic Freedom and Entrepreneurial Activity: Some Cross-Country Evidence

2006-16 Nicolai J. Foss \& Giampaolo Garzarelli: Institutions as Knowledge Capital: Ludwig M. Lachmann's Interpretative Institutionalism

2006-17 Koen H. Heimriks \& Jeffrey J. Reuer: How to Build Alliance Capabilities

2006-18 Nicolai J. Foss, Peter G. Klein, Yasemin Y. Kor \& Joseph T. Mahoney: Entrepreneurship, Subjectivism, and the Resource - Based View: Towards a New Synthesis

2006-19 Steven Globerman \& Bo B. Nielsen: Equity Versus Non-Equity International Strategic Alliances: The Role of Host Country Governance

\section{7}

2007-1 Peter Abell, Teppo Felin \& Nicolai J. Foss: Building Micro-Foundations for the Routines, Capabilities, and Performance Links 
2007-2 Michael W. Hansen, Torben Pedersen \& Bent Petersen: MNC Strategies and Linkage Effects in Developing Countries

2007-3 Niron Hashai, Christian G. Asmussen, Gabriel R.G. Benito \& Bent Petersen: Predicting the Diversity of Foreign Entry Modes

2007-4 Peter D. Ørberg Jensen \& Torben Pedersen: Whether and What to Offshore?

2007-5 Ram Mudambi \& Torben Pedersen: Agency Theory and Resource Dependency Theory: Complementary Explanations for Subsidiary Power in Multinational Corporations

2007-6 Nicolai J. Foss: Strategic Belief Management

2007-7 Nicolai J. Foss: Theory of Science Perspectives on Strategic Management Research: Debates and a Novel View

2007-8 Dana B. Minbaeva: HRM Practices and Knowledge Transfer in MNCs

2007-9 Nicolai J. Foss: Knowledge Governance in a Dynamic Global Context: The Center for Strategic Management and Globalization at the Copenhagen Business School

2007-10 Paola Gritti \& Nicolai J. Foss: Customer Satisfaction and Competencies: An Econometric Study of an Italian Bank

2007-11 Nicolai J. Foss \& Peter G. Klein: Organizational Governance

2007-12 Torben Juul Andersen \& Bo Bernhard Nielsen: The Effective Ambidextrous Organization: A Model of Integrative Strategy Making Processes.

\section{8}

2008-1 Kirsten Foss \& Nicolai J. Foss: Managerial Authority When Knowledge is Distributed: A Knowledge Governance Perspective

2008-2 Nicolai J. Foss: Human Capital and Transaction Cost Economics.

2008-3 Nicolai J. Foss \& Peter G. Klein: Entrepreneurship and Heterogeneous Capital.

2008-4 Nicolai J. Foss \& Peter G. Klein: The Need for an Entrepreneurial Theory of the Firm.

2008-5 Nicolai J. Foss \& Peter G. Klein: Entrepreneurship: From Opportunity Discovery to Judgment.

2008-6 Mie Harder: How do Rewards and Management Styles Influence the Motivation to Share Knowledge?

2008-7 Bent Petersen, Lawrence S. Welch \& Gabriel R.G. Benito: Managing the Internalisation Process - A Theoretical Perspective.

2008-8 Torben Juul Andersen: Multinational Performance and Risk Management Effects: Capital Structure Contingencies. 
2008-9 Bo Bernard Nielsen: Strategic Fit and the Role of Contractual and Procedural Governance in Alliances: A Dynamic Perspective.

2008-10 Line Gry Knudsen \& Bo Bernhard Nielsen: Collaborative Capability in R\&D Alliances: Exploring the Link between Organizational and Individual level Factors.

2008-11 Torben Juul Andersen \& Mahesh P. Joshi: Strategic Orientations of Internationalizing Firms: A Comparative Analysis of Firms Operating in Technology Intensive and Common Goods Industries.

2008-12 Dana Minbaeva: HRM Practices Affecting Extrinsic and Intrinsic Motivation of Knowledge Receivers and their Effect on Intra-MNC Knowledge Transfer.

2008-13 Steen E. Navrbjerg \& Dana Minbaeva: HRM and IR in Multinational Corporations: Uneasy Bedfellows?

2008-14 Kirsten Foss \& Nicolai J. Foss: Hayekian Knowledge Problems in Organizational Theory.

2008-15 Torben Juul Andersen: Multinational Performance Relationships and Industry Context.

2008-16 Larissa Rabbiosi: The Impact of Subsidiary Autonomy on MNE Knowledge Transfer: Resolving the Debate.

2008-17 Line Gry Knudsen \& Bo Bernhard Nielsen: Organizational and Individual Level Antecedents of Procedural Governance in Knowledge Sharing Alliances.

2008-18 Kirsten Foss \& Nicolai J. Foss: Understanding Opportunity Discovery and Sustainable Advantage: The Role of Transaction Costs and Property Rights.

2008-19 Teppo Felin \& Nicolai J. Foss: Social Reality, The Boundaries of Self-fulfilling Prophecy, and Economics.

2008-20 Yves Dos, Nicolai J. Foss \& José Santos: A Knowledge System Approach to the Multinational Company: Conceptual Grounding and Implications for Research

2008-21 Sabina Nielsen \& Bo Bernhard Nielsen: Why do Firms Employ foreigners on Their Top Management Teams? A Multi-Level Exploration of Individual and Firm Level Antecedents

2008-22 Nicolai J. Foss: Review of Anders Christian Hansen's “Uden for hovedstrømmen - Alternative strømninger i økonomisk teori"

2008-23 Nicolai J. Foss: Knowledge, Economic Organization, and Property Rights

2008-24 Sjoerd Beugelsdijk, Torben Pedersen \& Bent Petersen: Is There a Trend Towards Global Value Chain Specialization? - An Examination of Cross Border Sales of US Foreign Affiliates 
2008-25 Vikas Kumar, Torben Pedersen \& Alessandro Zattoni: The performance of business group firms during institutional transition: A longtitudinal study of Indian firms

2008-26 Sabina Nielsen \& Bo B. Nielsen: The effects of TMT and Board Nationality Diversity and Compensation on Firm Performance

2008-27 Bo B. Nielsen \& Sabina Nielsen: International Diversification Strategy and Firm Performance: A Multi-Level Analysis of Firm and Home Country Effects

\section{9}

2009-1 Nicolai J. Foss: Alternative Research Strategies in the Knowledge Movement: From Macro Bias to Micro-Foundations and Multi-Level Explanation

2009-2 Nicolai J. Foss \& Peter G. Klein: Entrepreneurial Alertness and Opportunity Discovery: Origins, Attributes, Critique

2009-3 Nicolai J. Foss \& Dana B. Minbaeva: Governing Knowledge: The Strategic Human Resource Management Dimension

2009-4 Nils Stieglitz \& Nicolai J. Foss: Opportunities and New Business Models: Transaction Cost and Property Rights Perspectives on Entrepreneurships

2009-5 Torben Pedersen: Vestas Wind Systems A/S: Exploiting Global R\&D Synergies

2009-6 Rajshree Agarwal, Jay B. Barney, Nicolai J. Foss \& Peter G. Klein: Heterogeneous Resources and the Financial Crisis: Implications of Strategic Management Theory

2009-7 Jasper J. Hotho: A Measure of Comparative Institutional Distance

2009-8 Bo B. Nielsen \& Sabina Nielsen: The Impact of Top Management Team Nationality Diversity and International Experience on Foreign Entry Mode 